Egyptian Journal of Aquatic Biology \& Fisheries

Zoology Department, Faculty of Science,

Ain Shams University, Cairo, Egypt.

ISSN 1110 - 6131 Vol. 21(1): 73-85 (2017)

www.ejabf.js.iknito.com

\title{
Impact of different lining substrata on biological and biochemical characteristics of
} the Nile Tilapia Oreochromis niloticus

\author{
Khalil, M. T. ${ }^{1 *}$; Ismail, N. M. M. ${ }^{2}$; Mohamed, I. K. ${ }^{1}$ and Ali, S.E. ${ }^{2}$ \\ 1- Zoology Department, Faculty of Science, Ain Shams University, Cairo, Egypt. \\ 2- Environmental Research and Medical Malacology Department, Theodor Bilharz Research Institute, \\ Cairo, Egypt.
}

\section{ARTICLE INFO}

Article History:

Received: Jan, 2017

Accepted: Feb.2017

Available online: May 2017

\section{Keywords:}

Lining media,

Oreochromis niloticus

Growth performance

Biochemistry

Electrophoretic protein

SDS-PAGE.

\section{ABSTRACT}

The effect of lining waterbodies on the growth performance and survival rate of the fish Oreochromis niloticus maintained in different lining substrata (cement, plastic and mud) and control (without lining) for 12 weeks was studied. It was found that there was no significant difference in the final mean size (length and weight) among the different groups; the fish length were $18.01 \pm 0.26,17.73 \pm 0.15,17.33 \pm 0.2$ and $17.83 \pm 0.14 \mathrm{~cm}$ for cement, plastic, mud and control, respectively and weight (15.94 \pm 0.11 , $15.73 \pm 0.2,15.52 \pm 0.34$ and $15.39 \pm 0.26 \mathrm{~g}$ for cement, plastic, mud and control respectively. The calculated condition factor (K-value) was $0.27 \pm 0.01,0.28 \pm 0.0,0.3 \pm 0.0$ and $0.27 \pm 0.0$ for fish maintained in cement, plastic, mud and control, respectively; which also wasn 't significantly differ among the study groups. In addition, determination of length increment (LI), the average weight gain (AWG), average daily weight gain (ADWG), the relative growth rate (RGR \%) and specific growth rate (SGR \%) of $O$. niloticus indicated that there is no significant differences obtained between the lining materials and control ones. In the same way, the biochemical analysis of the blood show no significant differences among fish groups maintained in different substrata. The electrophoretic patterns of tissue soluble-proteins extracted from the fish maintained in the tested lining media (mud, cement, and plastic) and control ones for a period of 12 weeks were also studied. It was found that the control group yielded 12 protein fractions of molecular masses between 165.24 and 12.34kDa. Whereas, only 11 protein bands appeared in fish group maintained in cement substratum ranging from 162.62 to $12.15 \mathrm{kDa}$. Fish groups maintained in plastic and mud substratum obtained the same number of protein bands (14 bands) with molecular weight varied from 152.54 to 12.49 and from 165.24 to 12.34 $\mathrm{kDa}$, respectively. Fish in cement group demonstrates the highest similarity indices with the two groups; control and mud with similarity index of 0.96 and 0.88 , respectively. While the plastic fish groups show a similarity index of 0.69 and 0.79 with the same groups, respectively. It could be concluded that the application of lining the waterbodies (whatever the used material) hasn't negative impact, on the growth performance, blood biochemical analysis and the protein profiles, comparing to the mud and control groups. 


\section{INTRODUCTION}

Water is a key element of all life aspects especially in the agricultural production. Open channels system is the main water supply intervention in the irrigation scheme in most regions around the world. However, a majority of these schemes are often criticized for their water losses. Water losses comprises of both evaporation and seepage. The evaporation loss is the function of temperature, humidity and wind velocity, while the main reasons for water seepage are leakages from holes made by rodents, high density of vegetation (transpiration), un-compacted weak banks and lack of maintenance (Bikram, 2015). Since water suitable for human consumption, livestock and irrigation is limited in many parts of the world, so water must be saved to be available when and where it is required (FAO, 2012). The issue of water losses through irrigation systems has major impacts on surface water supplies and needs management. It is, therefore, very essential to properly conserve this resource and regulate its use to obtain maximum benefits.

It is not practicable to prevent evaporation loss in running water. However, seepage losses could be effectively minimized by the use of an impervious medium between the porous soil and the water flowing in the system i.e. canal lining (Arshad et al., 2009). Lining of watercourses is one of the environmental modifications that came to introduce a lot of benefits to the ecosystem as well as man who is the most important consumer. These benefits include: water conservation, no seepage of water and reduction in maintenance cost (WAPDA, 2004). Lining of main watercourses also attempts to save water of a good quality for better effectiveness and sustainable water management for all the shareholders who use it (Azzam et al., 2016). Nowadays, applying the artificial construction of the earthen ponds became wildly used by fish producers for the sake of the world economic purposes. In Nigeria, aquaculture has been practiced in various media ranging from concrete tanks to plastic ones and earthen pond (NAERLS, 2009).

Fishes are one of the most indicative factors in freshwater systems; they greatly affected by any changes of their surroundings (Mahmoud, 2002). So, fish are usually considered as organisms of choice for assessing the effects of any environmental changes in the aquatic ecosystem (Borkovic et al., 2008). Fishes are the only taxa in water that are directly exploited by man; they represent a significant protein source for human beings (Agah et al., 2009). Oreochromis niloticus (Nile tilapia) is an important fish species in commercial fisheries of Egypt and they are one of the most favorable fish type for eating around the world. O. niloticus is the second to carps as the most widely farmed freshwater fish in the world (FAO, 2009).They are among the most resistant fishes against diseases and relatively bad environmental conditions such as: high stock density, low dissolved oxygen; less than $0.5 \mathrm{mg} / \mathrm{l}$ and wide range of salinity (Hasheesh et al., 2011).

The growth performance of the fish refers to the fish weight at a given body length. The relative wellbeing in fish can be assessed through length-weight and length-length relationships (King, 1996). These relationships have been widely used on different fish species in the laboratory researches to study the effects of certain ingredients or diet-borne toxins (Ogunji et al., 2008; Ghazalah et al., 2010; Gao and Lee, 2012) and in the field investigations to understand the effect of water quality on the growth performance of fish (Taiwo and Aransiola, 2001; Fafioye and Oluajo, 2005; Laleye, 2006)

Gel electrophoresis is a broad subject encompassing many different techniques. Sodium dodecyl sulfate polyacrylamide gel electrophoresis (SDS-PAGE) is the most commonly practiced technique used to separate proteins according to their molecular 
weights (Jesslin et al., 2013). It provides an easy way to estimate the number of polypeptides fractions in samples, thus allowing samples from different sources to be compared for their protein content.

The present work aims to investigate the impact of different lining materials (cement and plastic as well as mud substratum of the water media), under laboratory conditions, on the growth performance, the survival rate and the electrophretic protein pattarens of the fish Oreochromis niloticus using SDS polyacrylamide gel electrophoresis. In addition to study their impact on the physico-chemical parameters of water such as temperature, hydrogen ion concentration $(\mathrm{pH})$, dissolved oxygen (DO), electric conductivity (EC) and total dissolved solids (TDS).

\section{MATERIAL AND METHODS}

\section{Oreochromis niloticus (Linnaeus, 1766):}

Healthy Nile tilapias, $O$. niloticus, were obtained alive from the fish hatchery at El-Abbassa, Sharkeya governorate, Egypt. Fish were transported to the laboratory in plastic bags containing de-chlorinated water and aerated with oxygen. All fish were acclimated for two weeks in glass aquaria before being used in the experiments.

\section{Aquaria:}

The experiments were carried out in four groups of aquaria $(50 \times 30 \times 35 \mathrm{~cm})$; three replicates for each group. The first group was lined with cement from all sides, the second one was lined with plastic material, the third one was provided with sterile muddy substratum and the last group was left as a control (glass aquaria) without lining. Each aquarium was provided with about 30 liter de-chlorinated tap water and supplied with compressed air from air pumps via air-stones. A three quarter of aquarium's water was siphoned daily along with fish excreta and replaced with an equal volume of clean water of the same temperature. The ambient temperature throughout the study ranged from 24 to $28^{\circ} \mathrm{C}$.

\section{The physico-chemical parameters:}

Water quality parameters in each aquarium were measured twice a week during the experimental period. These parameters were including temperature (via a thermometer), pH-value (using HANNA instrument Inc., Model HI 9125 -pH-meter, Woonsocket-USA, ROMANIA), dissolved oxygen (DO) (using HANNA instrument Inc., Model 9146-dissolved oxygen meter, Woonsocket-USA, ROMANIA), electrical conductivity (EC) and total dissolved solids (TDS) (by HANNA instrument Inc., Mode 19635-EC/TDS meter). All mean values of water parameters during the experiment are presented in tabulated forms.

\section{Design of the experiments:}

A total number of $120 \mathrm{fish}$; about $5 \mathrm{~cm}$ and $3 \mathrm{~g}$ (10 fish/ aquarium), were used in this experiment. Fish were individually weighed to the nearest $0.1 \mathrm{~g}$ and length was measured to the nearest $0.1 \mathrm{~cm}$ then distributed into the experimental aquaria. Fish were fed on the commercial fish diet with a rate of $3 \%$ of live body weight divided into 2 equal meals provided to fish twice a day (Eurell et al., 1978). Each fish was weighed and the total length was measured biweekly throughout the experimental period (12 weeks), also the amount of food was re-adjusted based on the actual body weight changes. The growth rate of fish was recorded biweekly and the results were illustrated in graphic form.

The growth performance of Oreochromis niloticus:

The growth parameters were calculated by the following equations according to Jobling (1983).

Net increase in length $(\mathbf{N I L})(\mathrm{cm})=$ Final length - Initial length 
Percentage net increase in length $(\%$ NIL $):=\frac{N I L(\mathrm{~cm})}{\mathrm{X}} 100$

Initial length $(\mathrm{cm})$

Net increase in weight $(\mathbf{N I W} ; g)=$ Final weight - Initial weight

Percentage net increase in weight $(\% \mathbf{N I W})=\frac{\mathrm{NIW}(\mathrm{g})}{\text { Initial weight }(\mathrm{cm})} \mathrm{X} 100$

Fulton condition factor $(\mathbf{K})$ of the fish was calculated for each individual fish using the equation of Schreck and Moyle (1990).

$$
(\mathrm{K})=\frac{\text { Wet fish weight }(\mathrm{g}) \times 100}{\text { Total fish length }\left(\mathrm{cm}^{3}\right)}
$$

Body length increment $(\mathrm{LI} ; \mathrm{cm})=L_{1}-L_{0}$

Where: $\mathrm{L}_{1}=$ Average final total length $(\mathrm{cm})$

$\mathrm{L}_{0}=$ Average initial total length $(\mathrm{cm})$

Average body weight gain (AWG) was estimated according to the equation of (Jauncey and Ross, 1982):

Where: $\mathrm{W}_{1}=$ Average final weight $(\mathrm{g})$

$$
\mathrm{AWG}=\mathrm{W}_{1}-\mathrm{W}_{0}
$$

$\mathrm{W}_{0}=$ Average initial weight $(\mathrm{g})$

Average daily weight gain (ADWG; $g /$ fish/day): $=\underline{A W G(g)}$

Where: $t=$ experimental period in days.

Relative growth rate $(\mathbf{R G R} ; \%)=\frac{A W G}{W_{0}} \mathrm{X} 100$

Specific growth rate (SGR) is the percentage body weight gain per day; it was calculated using the equation of Allen and Wooton (1982).

$$
S G R=\frac{\ln \left(W_{1}\right)-\ln \left(W_{0}\right)}{t} \times 100
$$

Where: $S G R=$ Specific growth rate (\%/day).

$\ln \left(\mathrm{W}_{1}\right)=$ Natural Logarithm $(\log )^{-10}$ of the mean final weight of fish.

$\ln \left(\mathrm{W}_{0}\right)=$ Natural Logarithm $(\log )^{-10}$ of the mean initial weight of fish

$\mathrm{t}=$ Time in days.

\section{SDS-PAGE of the fish proteins:}

The electrophoresis technique of Laemmli (1970) was used to investigate any possible variations that would be found in the muscles proteins (sarcoplasmic proteins) of the tested fish. A piece of $1.0 \mathrm{~g}$ white dorsal epiaxial muscle from 5 fish $(0.2 \mathrm{~g}$ from each fish) was isolated then immediately stored at $-20^{\circ} \mathrm{C}$ until the processing. Tissue extracts were prepared by homogenizing the samples in a Tris- $\mathrm{HCl}$ buffer solution 0.1 $\mathrm{M}(\mathrm{pH}=6.8)$ in a 1: $10(\mathrm{w} / \mathrm{v})$ ratio using Pro-Scientific INC (Pro-SC-250, USA) homogenizer, then centrifuged at $4000 \mathrm{rpm}$ for 15 minutes at $4^{\circ} \mathrm{C}$ in cooling centrifuge; Kokusan H-100 BC, Japanese. The supernatants were pipetted into eppendorff vials and stored at $-20{ }^{\circ} \mathrm{C}$ until analysis. Protein samples were then boiled in water-bath for $5 \mathrm{~min}$. at $100{ }^{\circ} \mathrm{C}$ to obtain soluble protein. The soluble proteins were subjected to $15 \%$ SDS-PAGE gel, using vertical slab gel unit, followed by staining with Coomassie stain. Electrophoresis was carried out at a constant volt $(50 \mathrm{~V})$ in an electrode buffer composed of $0.195 \mathrm{M}$ glycine, $0.025 \mathrm{M}$ Tris- $\mathrm{HCl}$ and $0.1 \% \mathrm{SDS}, \mathrm{pH}$ 8.3 (Sambrook and Russell 2001).

The blood biochemical parameters of Oreochromis niloticus:

A similar set of aquaria was used. A total number of 80 fish ranging from 30$70 \mathrm{~g}$ in weight and $12-17 \mathrm{~cm}$ in length were distributed as 10 fish to each prepared aquarium. The experiment was carried out for 6 weeks as a chronic time period to investigate the impact of the different substrata on the blood parameters of the tested 
fish. At the end of the experiment, blood samples were collected individually from fish in each lining group and the control one (6 live fish from each group) and prepared for the biochemical assays. All mean values of serum parameters were presented in a tabulated form.

Statistical analysis:

Data of more than three different groups were subjected to One-way analysis of variance (ANOVA) to compare between them .If ANOVA indicated significance, the least significant difference (LSD) test was used to determine differences among means (Gill, 1981). Differences were considered significant at $P<0.05$. Statistical analysis was performed using Statistical Package for the Social Sciences (SPSS) software (version 11, SPSS Inc., Chicago, USA).

\section{RESULTS}

\section{Water quality parameters:}

The different physico-chemical parameters of water during maintaining the fish in aquaria with different lining substrata (mud, plastic and cement) and the control one (without lining) for 12 weeks are found in table (1). There was no clear variations in the average values of water temperature in all aquaria approximately as the same which varied between $22.23 \pm 0.46 \mathrm{C}^{\circ}$ in aquaria with cement, $22.34 \pm 0.46 \mathrm{C}^{\circ}$ in plastic, $22.07 \pm 0.46 \mathrm{C}^{\circ}$ in mud substratum and $22.42 \pm 0.41 \mathrm{C}^{\circ}$ for the control one. Also, the $\mathrm{pH}$ values were slightly neutral; they were ranging between 7.42 and 7.48 in all lined aquaria and the control one. On the other hand, the recorded mean value of the dissolved oxygen (DO) for water with mud substratum $(6.04 \mathrm{ppm})$ was significantly $(p<0.05)$ lower than those for water in aquaria lined with cement, plastic and control, which were represented by $6.57 \pm 0.09,6.46 \pm 0.04$ and $6.64 \pm 0.05$, respectively. Concerning the mean values of both conductivity and TDS of water, the values in aquaria with mud showed a significant higher $(p<0.05)$ values than those for cement, plastic and control.

Table 1: Statistical analysis of water parameters in different substrata.

\begin{tabular}{|c|c|c|c|c|c|c|}
\hline \multirow[t]{2}{*}{ Water parameter } & \multicolumn{4}{|c|}{ Substrata } & \multicolumn{2}{|c|}{ ANOVA } \\
\hline & Cement & Plastic & Mud & Control & $F$-value & $P$-Sig. \\
\hline $\begin{array}{l}\text { Temperature } \\
\left({ }^{\circ} \mathrm{C}\right)\end{array}$ & $\begin{array}{l}22.23^{\mathrm{a}} \\
\pm 0.42\end{array}$ & $\begin{array}{l}22.34^{\mathrm{a}} \\
\pm 0.46\end{array}$ & $\begin{array}{l}22.07^{\mathrm{a}} \\
\pm 0.46\end{array}$ & $\begin{array}{l}22.42^{\mathrm{a}} \\
\pm 0.41\end{array}$ & 0.117 & 0.949 \\
\hline pH & $\begin{array}{r}7.42^{\mathrm{a}} \\
\pm 0.19 \\
\end{array}$ & $\begin{array}{r}7.46^{\mathrm{a}} \\
\pm 0.19 \\
\end{array}$ & $\begin{array}{l}7.44^{\mathrm{a}} \\
\pm 0.17 \\
\end{array}$ & $\begin{array}{l}7.48^{\mathrm{a}} \\
\pm 0.19 \\
\end{array}$ & 0.170 & 0.997 \\
\hline $\begin{array}{c}\text { Dissolved Oxygen } \\
(\mathrm{mg} / \mathrm{l})\end{array}$ & $\begin{array}{r}6.57^{\mathrm{a}} \\
\pm 0.09\end{array}$ & $\begin{array}{r}6.46^{\mathrm{a}} \\
\pm 0.04\end{array}$ & $\begin{array}{l}6.04^{\mathrm{b}} \\
\pm 0.23\end{array}$ & $\begin{array}{r}6.64^{\mathrm{a}} \\
\pm 0.05\end{array}$ & 4.533 & 0.012 \\
\hline $\begin{array}{c}\text { Electrical } \\
\text { Conductivity } \\
(\mu \mathrm{mohs} / \mathrm{cm})\end{array}$ & $\begin{array}{l}510.25^{\mathrm{a}} \\
\pm 18.88\end{array}$ & $\begin{array}{l}463.21^{\mathrm{a}} \\
\pm 13.09\end{array}$ & $\begin{array}{l}667.00^{b} \\
\pm 59.17\end{array}$ & $\begin{array}{l}493.71^{\mathrm{a}} \\
\pm 26.78\end{array}$ & 6.992 & 0.002 \\
\hline $\begin{array}{c}\text { Total Dissolved } \\
\text { Salts(mg/l) }\end{array}$ & $\begin{array}{l}349.29^{\mathrm{a}} \\
\pm 17.76\end{array}$ & $\begin{array}{l}311.64^{\mathrm{a}} \\
\pm 17.03 \\
\end{array}$ & $\begin{array}{l}460.57^{\mathrm{b}} \\
\pm 43.26 \\
\end{array}$ & $\begin{array}{l}343.54^{\mathrm{a}} \\
\pm 13.75\end{array}$ & 6.343 & 0.003 \\
\hline
\end{tabular}

Data are expressed as mean \pm SE, $n=7$.

Means in the same row with different latter are statistically proved to be significantly different at $p<0.05$.

\section{Effect of lining materials on the growth performance of the Nile tilapia Oreochromis niloticus:}

Table (2) indicates that there is no significant difference in the final mean length $(18.01 \pm 0.26,17.73 \pm 0.15,17.33 \pm 0.2$ and $17.83 \pm 0.14 \mathrm{~cm}$ and weight $(15.94 \pm 0.11$, $15.73 \pm 0.2,15.52 \pm 0.34$ and $15.39 \pm 0.26 \mathrm{~g}$ ) for cement, plastic, mud and control respectively of the tested fish. However, the final mean length of fish was, in descending order; cement> control> plastic> mud, while the weight of fish was 
cement > plastic > mud> control. In addition, the calculated condition factor (K-value) was $0.27 \pm 0.01,0.28 \pm 0.0,0.3 \pm 0.0,0.27 \pm 0.0$ for fish maintained in cement, plastic, mud and control, respectively which wasn't also differ significantly among these groups. In the same way, the other biometric parameters; LI, AWG, ADWG, RGR and SGR showed the same results of being not significantly different among the fish maintained in different aquaria.

Table 2: Statistical analysis of the growth performance of Oreochromis niloticus reared in aquaria with different substrata for a period of 12 weeks.

\begin{tabular}{|l|c|c|c|c|c|c|}
\hline \multirow{2}{*}{ Biometric parameters } & \multicolumn{4}{|c|}{ Substrata } & \multicolumn{2}{c|}{ ANOVA } \\
\cline { 2 - 7 } & Cement & Plastic & Mud & Control & $\boldsymbol{F}$-value & $\boldsymbol{P}$-Sig. \\
\hline Initial length (cm) & $5.88 \pm 0.10$ & $5.77 \pm 0.08$ & $5.78 \pm 0.11$ & $5.86 \pm 0.09$ & 0.364 & 0.779 \\
\hline Final length (cm) & $18.10 \pm 0.14$ & $17.87 \pm 0.13$ & $17.80 \pm 0.18$ & $18.01 \pm 0.11$ & 0.590 & 0.625 \\
\hline Initial weight $(\mathrm{g})$ & $3.43 \pm 0.19$ & $3.34 \pm 0.15$ & $3.29 \pm 0.19$ & $3.43 \pm 0.18$ & 0.063 & 0.979 \\
\hline Final weight $(\mathrm{g})$ & $15.94 \pm 0.08$ & $15.92 \pm 0.16$ & $15.78 \pm 0.32$ & $15.70 \pm 0.21$ & 0.193 & 0.901 \\
\hline $\begin{array}{l}\text { Condition Factor } \\
\text { (k-value) }\end{array}$ & $0.72 \pm 0.18$ & $0.77 \pm 0.19$ & $0.75 \pm 0.19$ & $0.74 \pm 0.19$ & 0.014 & 0.998 \\
\hline LI (cm) & $2.04 \pm 0.13$ & $2.02 \pm 0.11$ & $2.00 \pm 0.11$ & $2.03 \pm 0.08$ & 0.014 & 0.998 \\
\hline AWG (g/fish) & $2.09 \pm 0.12$ & $2.10 \pm 0.09$ & $2.07 \pm 0.13$ & $2.05 \pm 0.08$ & 0.039 & 0.990 \\
\hline ADWG (g/fish/day) & $0.14 \pm 0.01$ & $0.14 \pm 0.01$ & $0.14 \pm 0.01$ & $0.14 \pm 0.01$ & 0.074 & 0.973 \\
\hline RGR (\%) & $30.20 \pm 7.13$ & $30.52 \pm 6.03$ & $29.93 \pm 5.94$ & $29.70 \pm 6.45$ & 0.003 & 1.000 \\
\hline SGR (\%/day) & $1.71 \pm 0.34$ & $1.74 \pm 0.30$ & $1.71 \pm 0.28$ & $1.69 \pm 0.31$ & 0.003 & 1.000 \\
\hline
\end{tabular}

- Data are expressed as mean \pm SE.

- Means in the same row are statistically proved to be not significantly different at $p<0.05$.

\section{Electrophoretic study:}

The SDS-PAGE of the skeletal muscle homogenate of O. niloticus from different experimental groups is presented in table (3) and figure (1). The electrophoretic analysis of protein of the control group yielded 12 fractions of molecular masses between 165.24 and $12.34 \mathrm{kDa}$.

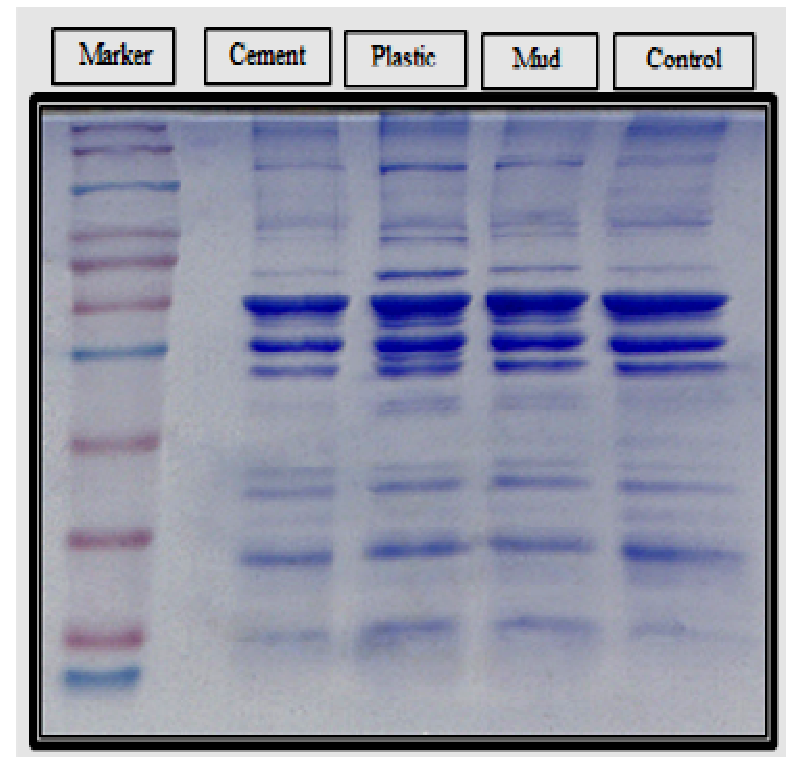

Fig. 1: SDS-PAGE showing the impact of different substrata on protein profiles of $O$. niloticus. 
Table 3: Protein banding profile of Growth performance of fish reared in different substrata.

\begin{tabular}{|c|c|c|c|c|c|c|c|c|c|c|}
\hline \multirow{2}{*}{ Bands } & \multirow{2}{*}{ Marker } & \multicolumn{9}{|c|}{ Substratum type } \\
\cline { 3 - 11 } & \multicolumn{2}{|c}{ Kement } & \multicolumn{2}{c|}{ Plastic } & \multicolumn{2}{c|}{ Mud } & \multicolumn{2}{c|}{ Control } \\
\cline { 2 - 11 } & KD & \% & KD & \% & KD & \% & KD & \% & KD & \% \\
\hline $\mathbf{1}$ & & & 162.62 & 9.36 & & & 165.24 & 3.90 & 165.24 & 9.20 \\
\hline $\mathbf{2}$ & 155 & 9.02 & & & 152.54 & 5.76 & & & & \\
\hline $\mathbf{3}$ & 120 & 7.93 & & & & & & & & \\
\hline $\mathbf{4}$ & & & 110.26 & 3.92 & & & 113.42 & 2.96 & 111.83 & 2.94 \\
\hline $\mathbf{5}$ & & & & & 101.32 & 3.76 & & & & \\
\hline $\mathbf{6}$ & 82 & 4.91 & 65.23 & 3.48 & 65.23 & 2.19 & 69.22 & 3.59 & 69.22 & 3.87 \\
\hline $\mathbf{7}$ & 62 & 5.83 & & & 60.72 & 1.73 & & & & \\
\hline $\mathbf{8}$ & 55 & 8.13 & 52.91 & 1.23 & 52.56 & 4.23 & 53.94 & 2.30 & 53.94 & 1.03 \\
\hline $\mathbf{9}$ & 45 & 5.94 & 44.62 & 27.13 & 44.62 & 25.92 & 45.00 & 29.97 & 44.62 & 31.60 \\
\hline $\mathbf{1 0}$ & & & & & 40.64 & 3.53 & 41.34 & 4.06 & & \\
\hline $\mathbf{1 1}$ & & & 35.48 & 21.70 & 35.48 & 17.50 & 36.08 & 19.14 & 35.48 & 19.65 \\
\hline $\mathbf{1 2}$ & 34 & 9.66 & 32.28 & 8.08 & 33.59 & 10.67 & 32.80 & 8.39 & 32.54 & 8.50 \\
\hline $\mathbf{1 3}$ & & & & & 29.55 & 2.95 & 29.91 & 3.78 & & \\
\hline $\mathbf{1 4}$ & 26 & 9.01 & & & & & 26.53 & 0.93 & & \\
\hline $\mathbf{1 5}$ & & & 22.75 & 4.07 & 23.23 & 1.14 & 24.06 & 1.76 & 23.40 & 3.36 \\
\hline $\mathbf{1 6}$ & & & 20.47 & 4.79 & 21.20 & 3.73 & 21.65 & 4.63 & 21.05 & 2.71 \\
\hline $\mathbf{1 7}$ & & & & & & & & & 18.16 & 1.11 \\
\hline $\mathbf{1 8}$ & 16 & 13.71 & 15.19 & 9.13 & 15.56 & 7.78 & 15.81 & 8.49 & 15.44 & 12.62 \\
\hline $\mathbf{1 9}$ & 12 & 13.19 & 12.15 & 7.09 & 12.49 & 9.10 & 12.54 & 6.03 & 12.34 & 3.27 \\
\hline $\mathbf{2 0}$ & 5 & 12.65 & & & & & & & & \\
\hline No. of bands & 11 & & 11 & & 14 & & 14 & & 12 & \\
\hline
\end{tabular}

- Data are expressed as mean $\pm \mathrm{SE}, \mathrm{n}=7$.

Whereas the fish grew in cement substratum gave up 11 protein bands ranging from 162.62 to $12.15 \mathrm{kDa}$. A total number of 14 bands were separated from fish of plastic and mud groups; they were varied from 152.54 to 12.49 and from 165.24 to $12.34 \mathrm{kDa}$, respectively. It was observed that all the groups shared nine bands.

Results in table (4) and figure 2 (dendogram) showed the similarity between the different groups of fish maintained in the different tested lining materials for 12 weeks. Higher similarity index "S" value was observed between cement and control groups (0.96) followed by 0.88 between cement and mud ones and 0.85 between mud and control groups. However, the lower similarity index (0.69) was observed between fish maintained in plastic and control group.

Table 4: Similarity indices of different protein patterns of muscles of Oreochromis niloticus reared in different habitat.

\begin{tabular}{|c|c|c|c|c|}
\hline Variables & Cement & Plastic & Mud & Control \\
\hline Cement & 1.00 & & & \\
\hline Plastic & 0.72 & 1.00 & & \\
\hline Mud & 0.88 & 0.79 & 1.00 & \\
\hline Control & 0.96 & 0.69 & 0.85 & 1.00 \\
\hline
\end{tabular}

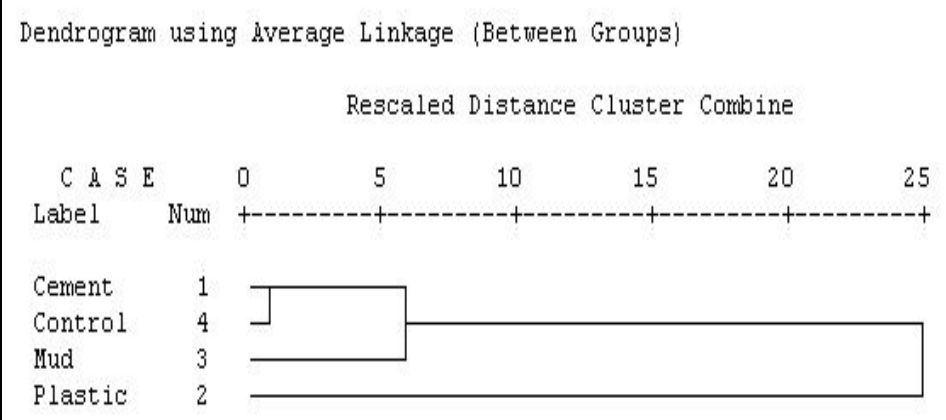

Fig. 2: Dendrogram of SDS-PAGE banding proteins. 


\section{Effect of lining materials on the biochemical analysis of the Nile tilapia; Oreochromis niloticus:}

The serum analysis of the fish maintained in different aquaria with different lining substrata and those of the control one show no significant differences in the tested biochemical parameters as shown in table (5).

Table 5: Impact of different substrata on the serum parameters of Oreochromis niloticus.

\begin{tabular}{|c|c|c|c|c|c|c|}
\hline \multirow{2}{*}{$\begin{array}{c}\text { Serum } \\
\text { parameters }\end{array}$} & \multicolumn{4}{|c|}{ Substrata } & \multicolumn{2}{c|}{ ANOVA } \\
\cline { 2 - 6 } Cement & Plastic & Mud & Control & F- value & P-Sig. \\
\hline Glucose & 70.13 & 70.01 & 69.41 & 70.15 & 0.078 & 0.971 \\
(mg/dl) & \pm 1.33 & \pm 1.23 & \pm 1.27 & \pm 1.23 & & \\
\hline ALP & 50.89 & 49.72 & 49.95 & 51.37 & 0.566 & 0.644 \\
( IU/L) & \pm 1.04 & \pm 1.02 & \pm 1.03 & \pm 1.05 & & \\
\hline ALT & 27.55 & 26.04 & 26.87 & 27.50 & 1.932 & 0.157 \\
( Units/ml) & \pm 0.53 & \pm 0.49 & \pm 0.49 & \pm 0.52 & & \\
\hline AST & 37.23 & 36.18 & 36.80 & 36.45 & 0.541 & 0.660 \\
(Units/ml) & \pm 0.62 & \pm 0.61 & \pm 0.62 & \pm 0.62 & & \\
\hline Total lipids & 1080.72 & 1083.23 & 1079.83 & 1081.09 & 0.014 & 0.998 \\
(mg/dl) & \pm 12.36 & \pm 12.37 & \pm 12.10 & \pm 11.92 & & \\
\hline Total proteins & 3.30 & 3.27 & 3.32 & 3.28 & 0.091 & 0.964 \\
(g/dl) & \pm 0.08 & \pm 0.07 & \pm 0.09 & \pm 0.08 & & \\
\hline Urea & 16.14 & 16.22 & 16.14 & 16.35 & 0.048 & 0.985 \\
(mg/dl) & \pm 0.44 & \pm 0.44 & \pm 0.44 & \pm 0.45 & & \\
\hline Creatinine & 0.83 & 0.83 & 0.86 & 0.81 & 1.632 & 0.214 \\
(mg/dl) & \pm 0.02 & \pm 0.02 & \pm 0.02 & \pm 0.02 & & \\
\hline
\end{tabular}

- Data are presented as mean \pm SE, $n=6$.

- Means in the same row are statistically proved to be not significantly different at $p<0.05$.

\section{DISCUSSION}

The water quality, in terms of physico-chemical and biological characteristics in the watercourses, controls the conditions that are responsible for the existence of fish (Gupta and Saxena, 2006). Thus, maintaining water with good quality is essential for both survival and optimum growth of the fish. Adeniji and Ovie (1982) stated that temperature, $\mathrm{pH}$, turbidity, salts, dissolved oxygen and free carbon dioxide as well as alkalinity are important factors that determine the quality of a waterbody and fish are mostly dependent on them for growth and development. Any change in any of these parameters may affect the growth, development and maturity of fish (Abdo, 2005). Gergis et al. (2008) stated that temperature affects the feeding rate of fish. Haswell et al. (1980) reported that the extreme increase and decrease in $\mathrm{pH}$ value in an aquatic ecosystem could cause disturbance in acid-base and iron regulation, fish growth and reproduction and sometimes leads to mortality. However, results of the present study revealed that there was no clear variation in the average values of water temperature and $\mathrm{pH}$ in all aquaria. Dissolved oxygen (DO) plays an important role in the quality of water and determines the usefulness of this water for most aquatic life forms. It depends on the chemical, physical and biochemical activities of water body. The life of fish depends, to a large extent, upon the amount of the DO present in water. The present recorded mean value of the dissolved oxygen of water with mud substratum was significantly $(\mathrm{p}<0.05)$ lower than those of water in aquaria lined with cement, plastic and control. The present results showed that both the conductivity and total dissolved salts (TDS) of water during maintaining the fish $O$. niloticus in aquaria with different lining substrata (cement, plastic and mud) and the control one (without lining) for 12 weeks were significant higher in aquaria with mud than those for 
cement, control and plastic $(\mathrm{p}<0.05)$. The total dissolved solids and the electrical conductivity are among the main factors affecting the survival and distribution of fishes (APHA, 2005).

The Nile tilapia, a native Egyptian fish, has become popular worldwide and is among the most cultivated fish species in Egypt. Thus, the present study was conducted to evaluate the effect of different substrata (cement, plastic and mud) on the growth performance, the electrophoretic pattern of the sarcoplasmic proteins of tested fish and the serum biochemical analysis. Present results revealed that there was a slightly variation (not significant) in the mean size (total length and weight) of the fish $O$. niloticus maintained in different lining substrata. However, fish maintained in cement aquaria recoded the bigest final mean size $(18.10 \mathrm{~cm}$ length and $15.94 \mathrm{~g}$ weight). These results disagree with a study carried out by Egware and Orewa (2013), in Nigeria, to the impact of using two different fish rearing facilities (earthen pond and concrete tank, of the same size; $9 \mathrm{~m} \times 9 \mathrm{~m} \mathrm{x} 1.4 \mathrm{~m}$ ) on the growth performance of catfish Clarias gariepinus. They used the same feeding regime and the same fish stocking density for six months till the market size. Results showed that final mean weight of the fish was greater in earthen pond $(0.62 \mathrm{~kg})$ than in concrete tank $(0.53$ $\mathrm{kg}$ ). This may be explained as our experiments were carried out in laboratory aquaria compared to the large size ponds used in their study.

SDS-PAGE is characterized by being a simple and reliable method in assaying the molecular weights of different proteins (Barriga-Sosa et al., 2004). Analysis of fish sarcoplasmic protein banding pattern is valuable, since these proteins are not denatured immediately after death unlike other proteins (Kjaersgård and Jessen, 2003). Furthermore, sarcoplasmic proteins include low molecular weight (40-60 kDa) proteins that can be extracted easily even from water and natural salt solutions (Love, 1997). In the present work, the obtained results indicate that there were slight differences in the total number of protein fractions separated from the fish of the tested groups which were 11, 14 and 14 bands for cement, plastic and mud groups, respectively comparing to the 12 band of the control group. This is suggesting that there was non-announcing effect of the different lining materials on the protein banding of the fish reared in them. There were many bands disappeared in fish maintained in the tested substrata (cement, plastic and mud) and present in the control and vice versa. It was found that there are 9 bands exhibited in all fish groups, they are supposed to be structural proteins.

Concerning the similarity index among the tested groups, it was calculated on the basis of band sharing according to Dice (1945). The present results indicated differences in similarity indices between different types of substrata and control. This may indicate that some factors were increased or decreased depending on the type of the substratum used. These alterations in protein fractionation and metabolic processes could be due to a production of additional proteins, or diminishing ones by the maintained fish in addition to disturbance of polypeptide metabolism. It is also obvious that fish in cement group demonstrates the highest similarity indices with the two groups (control and mud) with similarity index of 0.96 and 0.88 , respectively. These present results agree with those of Mosaad et al. (2012) who observed a good similarity indices between different groups of Biomphalaria alexandarina snails maintained in the same lining materials used in the present study (cement, plastic and mud) for different intervals. Also, Ryman et al. (1995) stated that there is a variability within species (among populations and also between individuals within a population), the presence of such variability is essential to their ability to survive and respond successfully to the environmental changes. Other study carried out by Komagata et al. (1991) indicated that there was sexual dimorphism in the electrophoretic patterns of 
blood serum proteins of a smelt (Hypomesus nipponensis). In such a way El-Deeb et al., (2014) applied the SDS-PAGE method on the sarcoplasmic protein for the purpose of finding the genetic variations among 5 sparid species (marine demersal fishes) from the northern coastal waters of Egypt. They also used the dendrogram to estimate the similarity among them. The dendrogram showed that the five sparid species are separated from each other into two clusters. They concluded that these data serve as a useful tool for genetic identification and differentiation.

Blood is a very good medium of assessing health status of animals (Taiwo and Anosa, 1995) and it reveals conditions within the body of the fish before there is any visible sign of disease (Fernandes and Mazon, 2003). Blood parameters are considered as a useful tool in diagnosing the functional status of the body in response to various stressors (Gupta and Saxena, 2006). In the present study, the blood analysis indicated that there is no negative effect on the fish maintained in the different substrata comparing to the control one.

In conclusion, the present results proved that lining (regardless the nature of its material) hasn't negative impact on the growth performance, physiological characteristics of the blood and the protein pattern of the fish as well as the water quality comparing to the mud and control groups. It can be concluded that the application of the lining watercourses isn't a bad matter that couldn't induce negative feedback on the aquaculture and the aquatic organisms including fish, that is most consumed by man.

\section{RECOMMENDATION}

From an economical point of view, lining is a good way for the management of the water and preserving it. From the studied types of lining materials; we could recommend using cement for lining purposes because of its resistance against the natural factors such as sun, wind and wild animals that wouldn`t need for renewing through short periods as the plastic materials.

\section{REFERENCES}

Abdo, M. H. (2005). Physico-chemical characteristics of Abu Za'baal ponds, Egypt. Egyptian Journal of Aquatic Research, 31: 1-15.

Adeniji, H. A. and Ovie, S. I. (1982). Study and appraisal of the water quality of the Asa, and Niger Rivers: National Institute for Freshwater Fisheries Research (NIFFR), Annual Report, pp. 15-20.

Agah, H.; Leermakers, M.; Elskens, M.; Fatemi, S. M. R. and Baeyens, W. (2009). Accumulation of trace metals in the muscles and liver tissues of five fish species from the Persian Gulf. Journal of Environmental Monitoring and Assessment, 157: 499- 514.

Allen, J.R. and Wooton, R. J. (1982). The effect of ration and temperature on the growth of the three-spined stickleback Gasterosteus aculeatus. Journal of Fish Biology, 20 (4): 409-422.

APHA (American Public Health Association) (2005). Standard Methods for the examination of Water and Wastewater. 20 th Ed., Washington, DC, pp. 11932950.

Arshad, M.; Ahmad, N.; Usman, M. and Shabbir, A. (2009). Comparison of water losses between unlined and lined watercourse in Indus Basin of Pakistan. Pak. J. Agri. Sci., 46: 280-284. 
Azzam, A. M.; Ismail, N. M. and Mostafa B. B. (2016). Impact of lining material on chemical and microbial irrigation water quality of Nubaria canal, Egypt. Asian Pac. J. Trop. Dis., 6: 126-132.

Barriga-Sosa, I.; Jimenez-Badillo, M.; Ibáńez, A. and Arredondo-Figueroa, J. (2004). Variability of tilapias (Oreochromis spp.) introduced in Mexico: morphometric, meristic and genetic characters. Journal of Applied Ichthyology, 20: 7-14.

Bikram, S. (2015). A Critical Study of Water Loss in Canals and its Reduction Measures. International J. Engin. Res. Applications, 5(3): 53-56.

Borkovic, S. S.; Pavlovic, S. Z.; Kovacevic, T. B.; Štajn, A. Š.; Petrović, V. M. and Saičić, Z. S. (2008). Antioxidant defence enzyme activities in hepatopancreas, gills and muscle of spiny cheek crayfish (Orconectes limosus) from the River Danube. Comparative Biochemisty and Physiology, Part C: Toxicology and Pharmacology, 147 (1): 122-128.

Dice, L. R. (1945). Measures of the amount of ecological association between species. Ecology, 26: 297-302.

Egware, R. A. and Orewa, S. I. (2013). A Comparative Profit Analysis of Catfish (ClariasGariepinus) Production in Ughelli, Delta State, Nigeria. International Journal of African and Asian Studies, 1: 1-3.

El-Deeb, S. I.; Ayman S. E., A. S.; Abo Gabal, A.A.M.; Hossam El-Din El-Wakee, H. E. and Ibrahim, N. A. E. (2014). Genetic divergence and phylogenetic relationship among five sparid species from the coastal waters of Egypt based on protein profiling and RAPD molecular markers. Life Science Journal, 11: 24.

Eurell, T. E.; Lewis, D. H. and Grumbles, L. C. (1978). Comparison of selected diagnostic tests for detection of motile Aeromonas septicemia in fish. American Journal of Veterinary Research, 39(8): 1384-1386.

Fafioye, O. O. and Oluajo, O. A. (2005). Length-weight relationship of five fish species in Epe lagoon, Nigeria. African J. Biotechnology, 4 (7): 749-751.

FAO (Food and Agriculture Organization of the United Nations, 2009). FAO yearbook. Fishery and aquaculture statistics. http://www.fao.org/fishery/publications/yearbooks/en.

FAO (Food and Agriculture Organization of the United Nations, 2012): Crop yield response to water. Prepared by P. Steduto, T.C. Hsiao, E. Fereres and D. Raes. FAO Irrigation and Drainage pp. 66- 500.

Fernandes, M. N. and Mazon, A. F. (2003). Environmental pollution and fish gill morphology. In: Val, A.L. and Kapoor B.G. (Eds.). Fish adaptation. Enfield, Science Publishers, pp. 203-231.

Gao, Y. and Lee, J. (2012). Compensatory Responses of Nile Tilapia Oreochromis niloticus under Different Feed-Deprivation Regimes. Fish. Aquat. Sci., 15(4): 305-311.

Gergis, R. B.; Fouda, M. M.; Abo-El-Hassan, A. A. and Ismail, N. M. (2008). Effect of the cichlid fish Oreochromis niloticus on Biomphalaria alexandrina snails under semi-field habitat. J. Biol. Chem. Environ. Sci., 3(1): 927-937.

Ghazalah, A. A.; Ali, H.M.; Gehad, E. A.; Hammouda, Y. A. and Abo-State, H. A. (2010). Effect of Probiotics on performance and nutrients digestibility of Nile tilapia (Oreochromis niloticus) Fed Low Protein Diets. Nature and Science, 8(5): $1-19$.

Gill, J.L. (1981): Design and Analysis of Experiments in Animal and Medical Sciences, vol. VI. The Iowa State Univ. Press, Ames, IA, U.S.A, 409 pp.

Gupta, P. and Saxena, P. G. (2006). Biochemical and haematological studies in freshwater fish Channa Punctatus exposed to synthetic pyrethroids. Pollution Research, 25 (3): 499-502. 
Hasheesh, W. S.; Marie, M. S.; Abbas, H. H.; Eshak, M. G. and Zahran, E. A. (2011). An Evaluation of the Effect of 17 $\alpha$-Methyl testosterone Hormone on some Biochemical, Molecular and Histological Changes in the Liver of Nile Tilapia; Oreochromis niloticus. Life Sci. J., 8: 343-358.

Haswell, M. S.; Randall, D. J. and Perry, S. F. (1980). Fish gill carbonic anhydrase: acid-base or salt transport. American Journal of Physiology, 238: 240-244.

Jauncey, K. and Ross, B. (1982). A guide to tilapia feeds and feeding. University of Stirling, Institute of aquaculture, Stirling, Scotland, pp.

Jesslin, G.; Sabaridasan, A.; Edwinthangam, P.; Palanikani, R. and Soranam, R. (2013). Electrophoretic Studies on the Muscle Proteins of Three Species of Genus Puntius (Osteichthyes Cyprinidae). International Journal of Research in Fisheries and Aquaculture; 3(2): 16-20.

Jobling, M. (1983). A short review and critique of methodology used in fish in growth and nutrition studies. Journal of Fish Biology, 23(6): 685-703.

King, R. P. (1996): Length-weight relationship of Nigerian freshwater fishes. NAGA: The ICLARM Quarterly, 19 (3): 49-52.

Kjaersgård, I. and Jessen, F. (2003). Proteome analysis elucidating postmortem changes in cod (Gadusmorhua) muscle proteins. Journal of Agricultural and Food Chemistry, 51: 3985-3991.

Komagata, K., Kawarabayashi, S. and Kuwabara, R. (1991). Sexual dimorphism in electrophoretic patterns of blood serum proteins in a smelt Hypomesusnipponensis. Nippon Suisan Gakkaishi: Formerly Bulletin of the Japanese Society for the Science of Fish, 57 (8): 1599.

Laemmli, U. K. (1970). Cleavage of the structural proteins during the assembly of the head of the bacteriophage T4. Nature, 227: 680-685.

Laleye, P. A. (2006). Length-weight and length-length relationship of fishes from the Oueme River in Benin (West Africa). Journal of Applied Ichthyology, 22: 330333.

Love, R. M. (1997). Biochemical dynamics and the quality of fresh and frozen fish. In: "Fish Processing Technology", (Ed.) Hall, G. M., Blackie Academic and Professional, Chapman \& Hall, London, pp. 1-26.

Mahmoud S. A. (2002). Evaluation of toxicity effect of some pollutants on histological feature and biochemical composition of Oreochromis niloticus L. living in River Nile (Damietta branch). Ph. D. Thesis Facility of Science Zagazig University, Egypt.

Mosaad, M. N. M.; Ismail, N. M. M. and Maraei, A. M. A. (2012). Comparative study of electrophoretic patterns of soluble proteins of Biomphalaria alexandrina Snails maintained in lining media of water system. J. Biol. Chem. Environ. Sci., 7(4): 499-528.

NAERLS (National Agricultural Extension Research and Liaison Services) (2009). construction of earthen ponds Extension guide no. 001. Compiled and Edited by: Dr. (Mrs.) Mabel Yarhere, Victoria Island, LAGOS, 20 p.

Ogunji, J.; Toor, R.S.; Schulz, C. and Kloas W. (2008). Growth Performance, Nutrient Utilization of Nile Tilapia Oreochromis niloticus Fed Housefly Maggot Meal (Magmeal) Diets. Turkish Journal of Fisheries and Aquatic Sciences, 8: 141-147.

Ryman, N.; Utter, F. and Laikre, L. (1995). Protection of intraspecific biodiversity of exploited fishes. Review of Fish Biology and Fisheries, 5: 417-446.

Sambrook, J. and Russell, D. W. (2001). Molecular Cloning. 3rd edition, Cold Spring Harbor Laboratory Press, Cold Spring Harbor, NY, USA. 
Schreck, C.B. and Moyle, P.B. (1990). Methods of Fish Biology. American Fisheries Society, Bethesda, Maryland, USA. pp. 363-387.

SPSS (Statistical Package for the Social Sciences) software (2001): Version 11, SPSS Inc., Chicago, USA.

Taiwo, I. O. and Aransiola, M. O. (2001). Length-weight relationship, condition factors and fecundity of Chrysichthysnigrodigitatuswalkeri in Asejiere Lake. Proceedings of the ${ }^{16}$ th Annual Conference of the Fisheries Society of Nigeria, Maiduguri, pp. 277-281.

Taiwo, V. O. and Anosa, V. O. (1995). Fibrinogen, leucocyte and haematocrit values of cattle with various disease conditions. Trop. Vet., 13:51-57.

WAPDA (Water and Power Development Authority) (2004). Impact of watercourse improvement on farm economy. Mona Reclamation Experimental Project, Bhalwal, 260:18-19.

\section{ARABIC SUMMARY}

\section{تأثير مواد تبطين مختلفة على الصفات البيولوجية والبيوكيميائية لاسماك البلطى النيلى (أوريوكرومس نيلوتيكس)

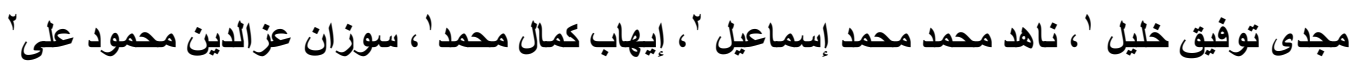

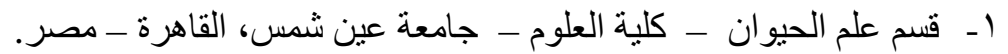

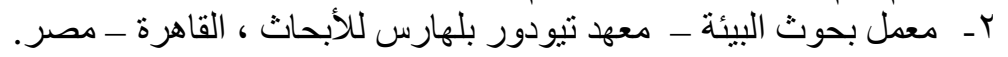

أجريت الدراسة الحالية من أجل تقييم تأثير التبطين (كوسيلة فيزيائية لإدارة المياه) على جودة المياه و على الئى

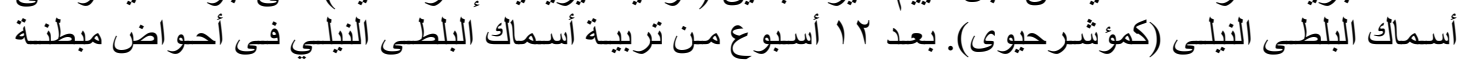

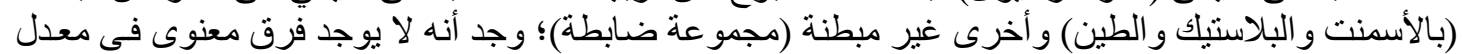

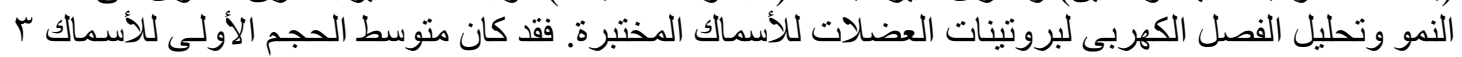

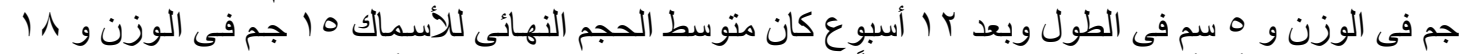

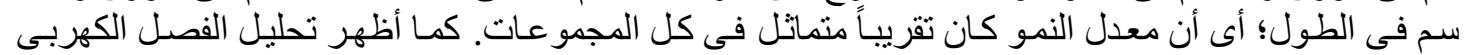

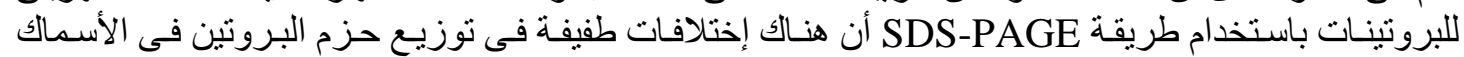

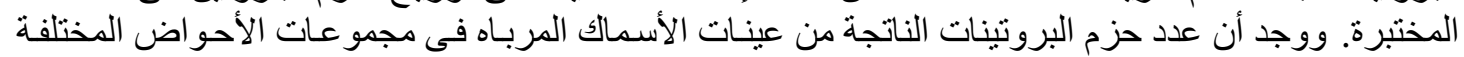

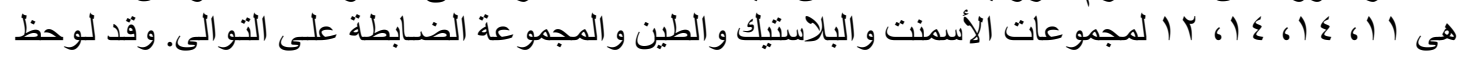

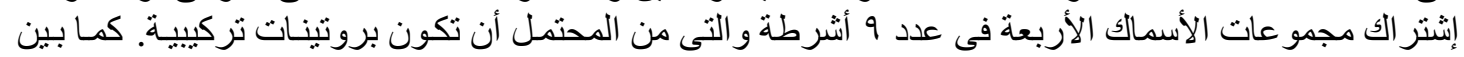

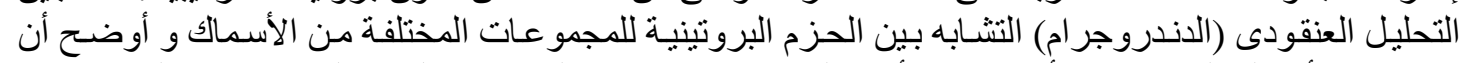

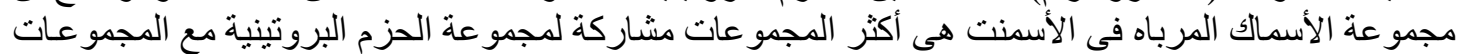

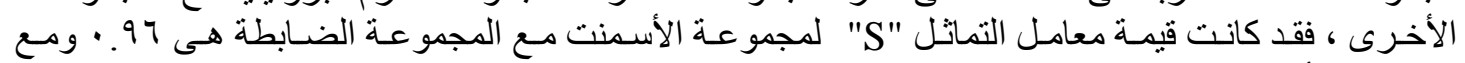

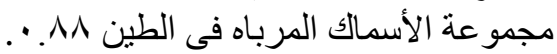

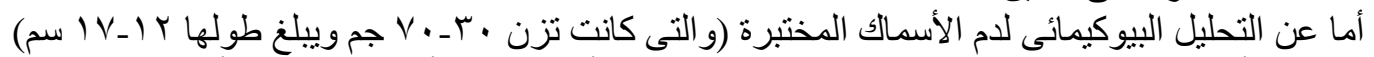

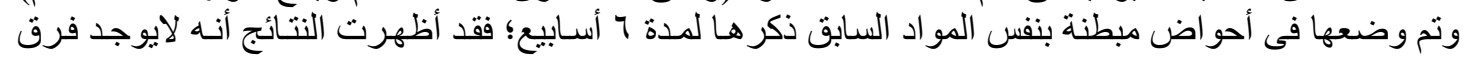

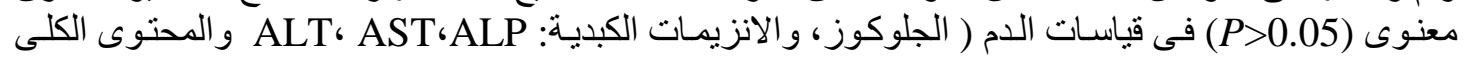


الطبيعة للمجمو عة الضابطة.

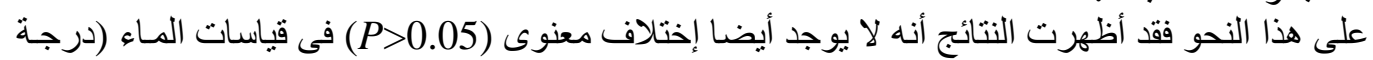

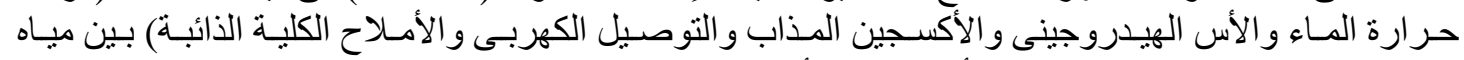



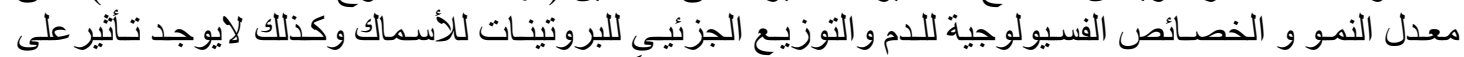

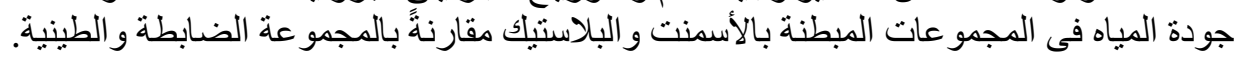

